\title{
Synergistic Effect of Chitosan and Clove Oil on Raw Poultry Meat
}

\author{
Mukhtar S, Zahoor T, Randhawa MA, Iqbal R*, Shabbir A, Liaqat A and Ahsan S
}

National Institute of Food Science and Technology, University of Agriculture, Faisalabad, Pakistan

\begin{abstract}
Poultry raw meat is a perishable and nutritious food and considered as a prime source of protein. Its high moisture content favors the bacterial growth and leads to deteriorative changes. Bacterial contamination and lipid oxidation reduce the quality and stability of chicken meat and ultimately result in social health concern. For the purpose of extending shelf life of meat and to prevent further bacterial contamination, antimicrobial based edible coatings (food grade material) are being widely used now days which also maintain the quality of meat. In present study, antimicrobial potential of chitosan and clove oil as coating material was checked on quality attributes of fresh poultry meat. The study was divided in to three phases; first phase deals with preparation of edible coating for its application on meat. In second phase, proximate composition of fresh raw chicken meat was checked prior to application of coating material followed by storage at refrigeration temperature ( 24 days). In last phase, chitosan based coated and uncoated (control) samples were studied periodically for microbial analysis (TPC) and sensory characteristics. The obtained results were subjected to statistical analysis and a significant difference $(p \leq 0.05)$ was observed among treatments. On over all basis, it was concluded that treatment, $\mathrm{T}_{4}$, containing $1 \%$ chitosan solution $+2 \%$ starch solution $+1.5 \mathrm{~mL}$ clove oil performed best due to their synergistic barrier properties against aerobic microbes and increased the shelf stability of raw meat in comparison to uncoated meat samples.
\end{abstract}

Keywords: Bacterial contamination; Chicken meat; Edible coating; Overall acceptability; Shelf life

\section{Introduction}

According to the Center for Disease Control and Prevention (CDC), 48 million people get sick, 128,000 are hospitalized, and 3000 die every year due to food borne diseases. Maintaining nutritional and organoleptic properties of food commodities as well as ensuring their microbiological safety is still the priority of present era [1]. Use of antimicrobial packaging is much feasible to provide safety and quality to refrigerated products [2]. Antimicrobial based package is considered as one of the types of active packaging [3,4]. The incorporation of active agents into packaging tends to create an environment inside the package which could delay/prevent the growth of microorganisms on product's surface and, hence, lead to extension in its shelf life [5].

An edible coating is responsible for better oxygen permeability, solute movement, provide good barrier properties to moisture, UV while ease in incorporation of nanoparticles, nanosensors, synthetic and natural antimicrobial agents $[6,7]$. These coatings also act as a host of various additives which impart a variety of functional properties in minimally processed foods [8]. Recently, edible coating and films are being used to decrease the oil uptake in fried foodstuffs. These are slight layers of edible stuffs, formed formerly, coated on foods which can prevent the growth of microorganism and can be used in replacement of synthetic plastics for food applications $[9,10]$.

The major advantages of edible film and coating are; it can be eaten with food product, prevents moisture losses during frozen storage, retains color of fresh meat, improves flavor and texture, resists lipid oxidation, reduces spoilage, and reduces environmental pollution (such as in poultry, seafood, frozen and processed meat) $[11,12]$.

Due to awareness in scientific community, natural antimicrobial agents (chitosan (CTS) and cloves) as a coating material are preferably used as an alternative to synthetic active packaging [13]. Chitosan is an abundant polysaccharides in nature (ranked second after cellulose) and has high molecular weight, usually attained by alkaline deacetylation of chitosan, present in exoskeleton of crustaceans, cell wall of fungus and other organisms $[14,15]$. It is demonstrated as a non-toxic, biofunctional, bio-degradable, bio-compatible and exerts antifungal as well as antibacterial effects in food matrices [16,17], although, it's antifungal activity is less as compared to antibacterial $[18,19]$. This food grade material comprises of three types of reactive functional groups, an amino group on C-6 position and two hydroxyl groups at C-6, C-3 positions which impart the antimicrobial potential to this substance $[20,21]$. Antimicrobial potential of chitosan has been reported against a wide variety of fungi, yeasts and bacteria [22-24].

Likewise, clove oil is also very useful preservative, flavor enhancer and exhibits antimicrobial activity [25]. This oil is obtained by the process of distillation of leaves, stems and flower of clove tree (Eugenia aromatic) and satisfies the criteria for being natural, safe, and healthy" preservatives $[16,26]$. The Food Drug Administration (FDA) described its recommended level for food application (normally not $>1500 \mathrm{ppm}$ ) and its daily intake level should be $2.5 \mathrm{mg} / \mathrm{kg}$ of body weight on the prescriptions by World Health Organization (WHO) [27].

It is a suitable material for designing food grade coatings and packaging structures for stored products in order to extend shelf life [28-30]. Keeping in view the excellent film and gas retaining capacities as well as good barrier properties, present study was designed to evaluate the antimicrobial effect of chitosan and clove oil on raw poultry meat and its effect on quality parameters in order to extend the shelf life during refrigeration storage.

\section{Materials and Methods}

\section{Procurement of raw materials}

Fresh raw poultry meat of uniform cuts, chemicals and other coating formulations were purchased from local market. The analysis

*Corresponding author: Rabia Iqbal, National Institute of Food Science and Technology, University of Agriculture, Faisalabad, Pakistan, Tel: +92 41 9200161; E-mail: rabi1300@hotmail.com

Received March 27, 2018; Accepted June 12, 2018; Published June 15, 2018

Citation: Mukhtar S, Zahoor T, Randhawa MA, Iqbal R, Shabbir A, et al. (2018) Synergistic Effect of Chitosan and Clove Oil on Raw Poultry Meat. J Food Process Technol 9: 737. doi: 10.4172/2157-7110.1000737

Copyright: @ 2018 Mukhtar S, et al. This is an open-access article distributed under the terms of the Creative Commons Attribution License, which permits unrestricted use, distribution, and reproduction in any medium, provided the original author and source are credited. 
was performed in Food Microbiology and Biotechnology Laboratory, National Institute of Food Science and Technology, University of Agriculture Faisalabad.

\section{Preliminary cleaning and proximate analysis of raw poultry meat}

Meat was cleaned to remove the blood residues and any dirt and then subjected to proximate analysis. Moisture, crude protein, fat and ash percentages were estimated from minced chicken by the published methods of AOAC [31].

\section{Preparation of coating solution and treatment of boneless chicken meat}

Antimicrobials based coating solutions were prepared according to modified procedure of Ojagha et al. [32]. To formulate the coating, following treatment plan was adopted (Table 1).

\section{Application of antimicrobial coating}

The prepared antimicrobial based coating solutions were applied on the boneless chicken meat. Prior to its application, meat was divided into five lots of uniform weight. One lot without coating application was considered as control while other four lots were dipped into coating solutions for $2 \mathrm{~min}$ and placed for drying for 15-20 min.

\section{Storage of the treated chicken meat}

Both coated and uncoated chicken meat samples were stored at refrigeration temperature $\left(4 \pm 1^{\circ} \mathrm{C}\right)$. Samples from each lot were evaluated (microbial analysis and sensorial evaluation after frying) at 6 days interval starting from day 0 up to 24 days.

\section{Microbial analysis of chicken meat}

For microbial count the method as described by Yetunde et al. [33] was followed. Nutrient agar was obtained as commercially dehydrated powder from local supplier. This was prepared according to manufacturer's instruction and was sterilized at $121^{\circ} \mathrm{C}$ and $15 \mathrm{psi}$ for $20 \mathrm{~min}$. The media was cooled slowly followed by pouring $\sim 20 \mathrm{~mL}$ into petri dishes separately and allowed to solidify. After that, the serially diluted sample $(0.01 \mathrm{~mL})$ was spread on respective plates. The petri plates with inoculated samples were then inverted and incubated at $37^{\circ} \mathrm{C}$ for $24 \mathrm{~h}$. The number of organisms was calculated by multiplying the count obtained from the selected dilution by reciprocal of the respective dilution factor, dividing the resultant by volume plated and expressed as Log CFU/g. The analysis was performed in triplicate to get precision.

\section{Sensory evaluation}

Sensory evaluation based on flavor, taste, texture, and overall acceptability was conducted by the panel of twenty trained and expert judges of National Institute of Food Science and Technology and scores were given by using 9 point hedonic scale ( $9=$ like extremely; $1=$ dislike extremely) method as described by Meilguaard et al. [34].

\begin{tabular}{|c|c|}
\hline Treatment & Concentration \\
\hline $\mathrm{T}_{0}$ & Control \\
\hline $\mathrm{T}_{1}$ & $0.5 \%$ chitosan solution $+2 \%$ starch solution $+1 \mathrm{~mL}$ clove oil \\
\hline $\mathrm{T}_{2}$ & $1 \%$ chitosan solution $+2 \%$ starch solution $+1 \mathrm{~mL}$ clove oil \\
\hline $\mathrm{T}_{3}$ & $0.5 \%$ chitosan solution $+2 \%$ starch solution $+1.5 \mathrm{~mL}$ clove oil \\
\hline $\mathrm{T}_{4}$ & $01 \%$ chitosan solution $+2 \%$ starch solution $+1.5 \mathrm{~mL}$ clove oil \\
\hline
\end{tabular}

Table 1: Treatment plan of study.

\section{Statistical analysis}

The numerical data obtained for each parameter was subjected to statistical analysis to determine the level of significance and comparison of means was carried out according to the method as described by Montgomery [35].

\section{Results and Discussion}

The mean values for moisture, crude protein, crude fat and ash percentages of fresh boneless chicken meat are presented in the Figure 1. It was demonstrated that the moisture content, protein content and ash varied from 73.7 to $75.8 \%, 22.0$ to $22.9 \%$, and 1.04 to $1.74 \%$ respectively, in boneless chicken meat samples. The findings of present investigations are in accordance with the results given by previous researchers [3638] who determined moisture, protein and fat contents which range between 74.2 to $75.38 \%, 19.51$ to $20.62 \%, 2.14$ to $4.48 \%$ accordingly. These researchers also noted non-significant difference in proximate composition of raw meat which supports the findings of the present study.

\section{Microbial analysis of chicken meat}

The effect of treatments, storage and their interaction (treatments $\times$ storage days) was found to be highly significant $(\mathrm{p}<0.01)$ on the total plate count (TPC) of refrigerated raw chicken meat. The main effects of storage days and treatment were significant $(p<0.05)$ indicative of the fact that there are differences in mean values of the dependent variable (TPC) for both the various storage periods and various treatments. The mean values of TPC for all five different treatments $\left(T_{0}, T_{1}, T_{2}, T_{3}\right.$ and $\mathrm{T}_{4}$ ) of raw chicken meat are given in Figure 2. The initial (day 0) TPC value for chicken meat (control and treated) was approximately 4.1 Log CFU/g which indicates the good quality of chicken meat, same observations were reported by Dawson et al. [39] and Latou et al. [40]. It is demonstrated from the Figure 2 that all treatments $\left(T_{0}, T_{1}, T_{2}, T_{3}\right.$, and $\mathrm{T}_{4}$ ) on zero day and $\mathrm{T}_{4}$ on $12^{\text {th }}$ day of storage differ non-significantly ( $\sum 4.2 \mathrm{Log}$ CFU/g). Similarly, $\mathrm{T}_{1}, \mathrm{~T}_{2}, \mathrm{~T}_{3}$ and $\mathrm{T}_{4}$ exhibited non-significant (3.39-3.08 Log CFU/g) effect on $6^{\text {th }}$ day of refrigerated storage. It was also noted that TPC did not reach a value of $7 \mathrm{Log}$ CFU/g, considered as the upper limit of TPC for fresh meat as defined by the ICMSF [41], during the whole period of storage ( 24 days). It was noticed from findings of present study that reductions in microbial counts (TPC) of treatments by dipping in chitosan solution were significantly lower

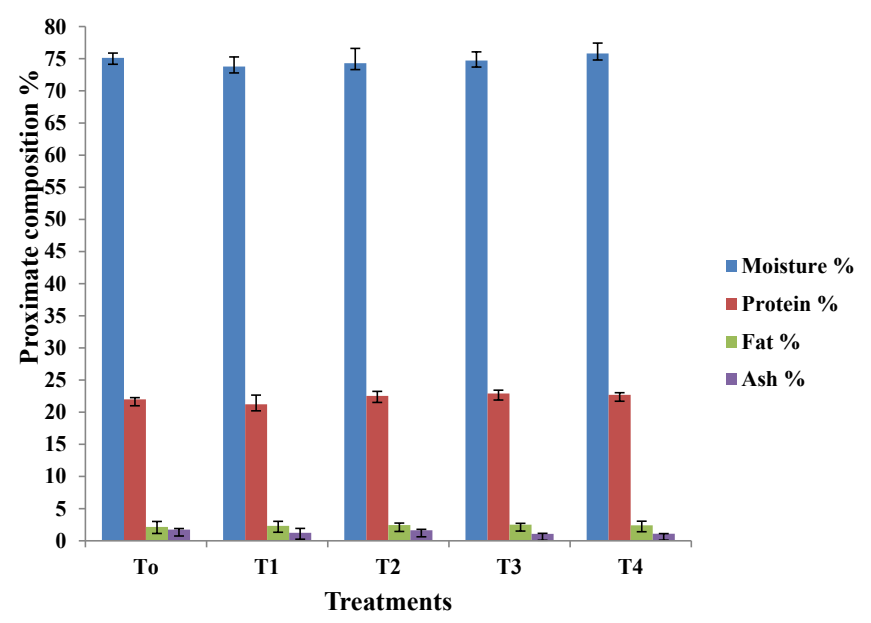

Figure 1: Proximate analysis of fresh raw chicken meat. 


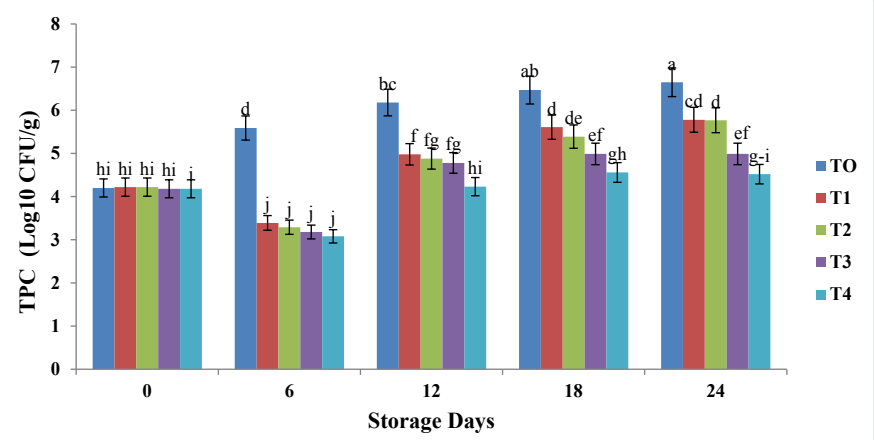

Figure 2: Effect of antimicrobial based coating on Total plate count (Log CFU/g) of boneless chicken meat.

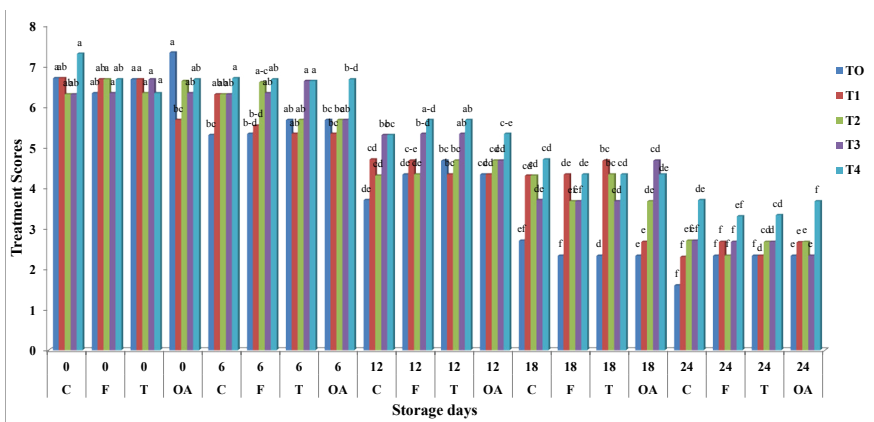

Figure 3: Effect of antimicrobial based coating on sensory attributes (scores) of boneless chicken meat.

( $\mathbf{C}^{*}$ for Color; $\mathbf{F}^{*}$ for Flavor; $\mathbf{T}^{*}$ for Texture; $\mathbf{O A}{ }^{*}$ for Overall acceptability)

than control sample. Similar results were reported previously for pork products [42], for minced beef patties [43] and for beef loins [44]. The inhibitory effect of chitosan in combination with modified atmosphere packaging (MAP) on growth of aerobic bacteria in ground chicken meat and chicken breasts has previously been demonstrated by Dawson et al. [39] and Chouliara et al. [45] and same antimicrobial potential of chitosan was reported as observed in our study.

\section{Sensory evaluation}

Sensory evaluation is an important tool in product development. Acceptance of a food product depends upon the consumers perception about the quality attributes of a particular food. The results regarding analysis of variance (ANOVA) for color, flavour, taste and overall acceptability of coated vs control meat samples demonstrated the highly significant effect $(\mathrm{p}<0.01)$. The results pertaining to mean score of sensory attributes (color, flavour, taste and overall acceptability) are depicted in Figure 3. The scores for color reveal that $\mathrm{T}_{4}$ was preferred by the judges because it gave excellent color to meat sample, followed by $\mathrm{T}_{1}$, $\mathrm{T}_{3}, \mathrm{~T}_{2}$ and $\mathrm{T}_{\mathrm{o}}$. The lowest color score was gained by uncoated treatment $\mathrm{T}_{\mathrm{o}}$ (control) which could be due to prevalence of various undesirable enzymatic and chemical changes in meat sample during storage period. During storage, the highest mean score for color gained by meat sample was noted for $\mathrm{T}_{4}(7.3 \pm 0.58)$ at 0 day. The score decreased significantly at $24^{\text {th }}$ day $(1.6 \pm 0.5)$ for $\mathrm{T}_{0}$. The score of color for the meat samples decreased with the passage of time for all the treatments. The results of present study are in line with the finding of Kanatt et al. [46], who also noted the change in color of chicken meat with the passage of time. The study findings are also comparable to Huang et al. [47], who reported that chitosan can be used to retard melanosis in meat samples during storage due to its potential to alleviate the melanosis phenomenon. This may be attributed to its certain functional properties, such as being an antioxidant, antimicrobial agent, and oxygen barrier.

It is deduced from the results pertaining to flavor of meat samples that the highest scores were assigned to $\mathrm{T}_{4}(4.86)$ followed by $\mathrm{T}_{3}(4.86)$, $\mathrm{T}_{1}$ (4.77) and $\mathrm{T}_{2}$ (4.72). The score 4.13 was the least for $\mathrm{T}_{\mathrm{o}}$ (control). The increased amount of clove oil $(1.5 \mathrm{~mL})$ in $\mathrm{T}_{4}$ could contribute in development of intense flavor/aroma in meat samples. During storage, the flavor score of meat sample were $6.67 \pm 0.58$ at 0 day for treatments $\mathrm{T}_{1}, \mathrm{~T}_{4}$ and $\mathrm{T}_{2}$ that decreased significantly to $24^{\text {th }}$ day. The result of present study are in line with the findings of Petrou et al. [48], who studied that flavor of treated boneless chicken meat decreased with the passage of time.

In case of scores for texture, the highest mean scores were allocated to $\mathrm{T}_{4}$ (5.25) followed by $\mathrm{T}_{3}$ (4.99), $\mathrm{T}_{2}$ (4.73) and $\mathrm{T}_{1}$ (4.66). The lowest scores were given to $\mathrm{T}_{\mathrm{o}}(4.33)$ which might be accounted to hardness on frying. The treatments $\left(\mathrm{T}_{1}, \mathrm{~T}_{3}\right.$ and $\left.\mathrm{T}_{\mathrm{o}}\right)$ got the maximum score for texture at 0 day of storage which decreased significantly till end of storage period. On overall basis, it was observed that texture of $\mathrm{T}_{4}$ acquired the highest score which can be related to maintenance of texture due to chitosan based coating along with higher concentration of clove oil. The results of present study are in line with the finding of Petrou et al. [48]. It is reported that as the coating provides a barrier between the meat and its surrounding environment which tends to maintain taste, texture and odor of stored meat up to a certain storage limit.

The results pertaining to overall acceptability of coated and uncoated meat samples are also displayed in Figure 3. It is evident from the results that coatings significantly affected the overall acceptability during storage period. The highest scores for overall acceptability during storage period (24 days) were attained for treatment $\mathrm{T}_{4}(3.67)$ followed by $\mathrm{T}_{2}, \mathrm{~T}_{1}$ and $\mathrm{T}_{3}$ and the lowest scores were noted for $\mathrm{T}_{\mathrm{o}}$ (2.33) on the same day. The results of current study are in line with findings reported by Wang et al. [17], who conducted study with aim to investigate the effect of chitosan-carvacrol coating with or without caprylic acid (CAP) on the quality of Pacific white shrimp during 10 days of iced storage. The result showed that chitosan-carvacrol coating significantly inhibited the increase in total aerobic plate count (TPC) of shrimp in comparison to control which definitely can improve the overall acceptability. It was deduced from their study that chitosancarvacrol coating may be promising to be used as active packaging for extending shelf life, and similarly, incorporation of clove oil may also enhance the efficacy of the coating as observed in present investigation.

\section{Conclusion and Recommendation}

The present study results suggested that chitosan and clove oil based coating were effective in inhibition of microbial growth in stored raw chicken meat and can be considered effective in maintaining the sensory quality of meat and meat products. The use of antimicrobial based coating for preservation of food item is a promising technology that can improve the quality of fresh meat products as well as increase their shelf life. Likewise, quality changes can be studied on meat and meat products by using other coating materials along with varying amounts and sources of essential oils other than clove oil. 
Citation: Mukhtar S, Zahoor T, Randhawa MA, lqbal R, Shabbir A, et al. (2018) Synergistic Effect of Chitosan and Clove Oil on Raw Poultry Meat. J Food Process Technol 9: 737. doi: 10.4172/2157-7110.1000737

\section{Conflict of Interest}

The authors declare that they have no conflict of interest.

\section{References}

1. Severino R, Vu KD, Donsì F, Salmieri S, Ferrari G, Lacroix M (2014) Antimicrobial effects of different combined non-thermal treatments against Listeria monocytogenes in broccoli florets. J Food Eng 124: 1-10.

2. Bento RA, Stamford TLM, Stamford TCM, de Andrade SAC, deSouza EL (2011) Sensory evaluation and inhibition of Listeria monocytogenes in bovine pate added of chitosan from Mucorrouxii. LWT-Food Sci Technol 44: 588-591.

3. Khanzadi M, Jafari SM, Mirzaei HA, Khodaeian F, Maghsoudlou Y, et al. (2015) Physical and mechanical properties in biodegradable films of whey protein concentrate-pullulan by application of beeswax. Carbohydr Polym 11: 24-29.

4. Arkoun M, Daigle F, Heuzey MC, Ajji A (2017) Antibacterial electrospun chitosan-based nanofibers: a bacterial membrane perforator. Food Sci Nutr 5: 865-874.

5. Sangsuwan J, Rattanapanone N, Rachtanapun P (2008) Effect of chitosan methylcellulose films on microbial and quality characteristics of fresh-cut cantaloupe and pineapple. Post-harvest Biol Technol 49: 403-410.

6. Arfat YA, Benjakul S, Vongkamjan K, Sumpavapol P, Yarnpakdee S (2015) Shelf-life extension of refrigerated sea bass slices wrapped with fish protein isolate/fish skin gelatin-ZnO nano composite film incorporated with basil lea essential oil. J Food Sci Technol 52: 6182-6193.

7. Ramos M, Valdes A, Mellinas AC, Garrigos MC (2015) New trends in beverage packaging systems: a review. Beverages 1: 248-272.

8. Mulla M, Ahmed J, Al-Attar H, Castro-Aguirre E, Arfat YA, et al. (2017) Antimicrobial efficacy of clove essential oil infused into chemically modified LLDPE film for chicken meat packaging. Food Control 73: 663-671.

9. Rojas-Graü MA, Avena-Bustillos RJ, Olsen C, Friedman M, Henika PR, et al. (2007) Effects of plant essential oils and oil compounds on mechanical, barrie and antimicrobial properties of alginate-apple puree edible films. J Food Eng 81: $634-641$

10. Bajer T, Silha D, Ventura K, Bajerova $P$ (2017) Composition and antimicrobia activity of the essential oil, distilled aromatic water and herbal infusion from Epilobium parviflorum Schreb. Ind Crop Prod 100: 95-105.

11. Hanna MA, Gennadios A, Kurth LB (1997) Application of edible coating on meat, polutryand sea foods. J Food Sci Tech 30: 337-350.

12. Arkoun M, Daigle F, Holley RA, Heuzey MC, Ajji A (2018) Chitosan $\square$ based nano fibers as bioactive meat packaging materials. Packag Technol Sci 31: 185-195.

13. Fernandez-Pan I, Mate JI, Gardrat C, Coma V (2015) Effect of chitosan molecular weight on the antimicrobial activity and release rate of carvacrolenriched films. Food Hydrocoll 51: 60-68.

14. Prabaharan M, Mano (2006) Chitosan derivatives bearing cyclodextrin cavities as novel adsorbent matrics. J Carbohydr Polym 63: 153-166.

15. Kerch G (2015) Chitosan films and coatings prevent losses of fresh fruit nutritional quality: a review. Trends Food Sci Technol 46: 159-166.

16. Cui H, Bai M, Rashed MM, Lin L (2018) The antibacterial activity of clove oil/ chitosan nano particles embedded gelatin nano fibers against Escherichia coli 0157: H7 biofilms on cucumber. Int J Food microbiol 266: 69-78.

17. Wang, Q, Lei J, Ma J, Yuan G, Sun H (2018) Effect of chitosan-carvacro coating on the quality of Pacific white shrimp during iced storage as affected by caprylic acid. Int J Boil Macromol 106: 123-129.

18. Tsai GJ, Wu ZY, Su WH (2000) Antibacterial activity of a chito oligosaccharide mixture prepared by cellulase digestion of shrimp chitosan and its application to milk preservation. J Food Prot 63: 747-7.

19. Ziani K, Fernandez-Pan I, Royo M, Mate JI (2009) Antifungal activity of films and solutions based on chitosan against typical seed fungi. Food Hydrocoll 23 2309-2314.

20. Xia WS (2003) Physiological activities of chitosan and its application in functional foods. J Chin Inst Food Sci Technol 3: 77-81.

21. Xia W, Liu P, Zhang J, Chen J (2011) Biological activities of chitosan and chitooligosaccharides. Food Hydrocoll 25: 170-179.
22. Severino R, Ferrari G, Vu KD, Donsì F Salmieri S, et al. (2015) Antimicrobial effects of modified chitosan based coating containing nano emulsion of essential oils: modified atmosphere packaging and gamma irradiation against Escherichia coli 0157:H7 and Salmonella typhimurium on green beans. Food Control 50: 215-222.

23. Yang $\mathrm{H}$, Zheng J, Huang C, Zhao X, Chen H, et al. (2015) Effects of combined aqueous chlorine dioxide and chitosan coatings on microbial growth and quality maintenance of fresh-cut bamboo shoots (phyllostachys praecox fprevernalis) during storage. Food Bioprocess Technol 8: 1011-1019.

24. Lekjing S (2016) A chitosan-based coating with or without clove oil extends the shelf life of cooked pork sausages in refrigerated storage. Meat Sci 111 192-197.

25. Muppalla SR, Kannat SR, Chawala SP, Sharma A (2014) Carboxymethy cellulose-polyvinyl alcohol films with clove oil for active packging of ground chicken meat. Food Packag Shelf Life 2: 51-58.

26. Ishlak A, Günal M, Abu Ghazaleh AA (2015) The effects of cinnamaldehyde monensin and quebracho condensed tannin on rumen fermentation, biohydrogenationand bacteria in continuous culture system. Anim Feed Sci Technol 207: 31-40.

27. Gulcin L, Elmastas M, Aboul-Enein HY (2012) Antioxidant activity of clove oil- A powerful antioxidant source. Arab J Chem 5: 489-499.

28. Caner C (2005) The effect of edible eggshell coatings on egg quality and consumer perception. J Sci Food Agric 85:1897-1902.

29. Tripathi S, Mehrotra GK, Dutta PK (2009) Physicochemical and bioactivity of cross-linked chitosan-PVA film for food packaging applications. Int J Biol Macromol 45: 372-376.

30. JonaidiJafari N, Kargozari M, Ranjbar R, Rostami H, Hamedi H (2018) The effect of chitosan coating incorporated with ethanolic extract of propolis on the quality of refrigerated chicken fillet. J Food Process Preserv 42: 1-8.

31. AOAC (2006) Official methods of analysis of Association of Official Analytical Chemist International. (18 ${ }^{\text {th }}$ edtn), AOAC Press Arlington Sci Tech.

32. Ojagh SM, Rezaei SH, Hosseini SMH (2010) Effect of Chitosan Enriched with the cinnamon Oil on the Quality of Rainbow Trout. J Food Chem 120:193-198.

33. Yetunde E, Alozie, Sonye UC (2015) Antimicrobial Activity of Moringa oleifera Leaf against Isolates of Beef Offal. Br Microbiol Res J 9:1-7.

34. Meligaard MC, Civille GV, Carr BT (2007) Sensory Evaluation Techniques. $\left(4^{\text {th }}\right.$ edtn), CRC Press LLC, New York.

35. Montgomery DC (2008) Design and Analysis of Experiments. ( $7^{\text {th }}$ edtn), Jhon Wiley and Sons. Inc Hoboken NJ, USA.

36. Chen HY, Elkasabi Y, Lahann J (2006) Surface modification of confined micro geometries via vapour-deposited polymer coating. J Am Chem Soc 128: 374-580.

37. Diaz O, Turienzo LR, Cobos A, Caride A, Vieties JM (2011) Whey protein- based coating on frozen Atlantic salmon (salmosalar): Influence of the plasticizer and the moment of coating on quality preservation. Food Chem 128: 187-194.

38. Mohan CO, Ravishankar CN, Lalitha KV, Gopal TS (2012) Effect of chitosan edible coating on the quality of double filleted Indian oil sardine (Sardinellalongiceps) during chilled storage. Food Hydrocoll 26:167-74.

39. Dawson PL, Han IY, Voller LM, Clardy CB, Martinez RM, et al. (1995) Film oxygen transmission rate effects on ground chicken meat quality. Poult Sci 74:1381-1387.

40. Latou E, Mexis SF, Badeka AV, Kontakos S, Kontominas MG (2014) Combined effect of chitosan and modified atmosphere packaging for shelf life extension of chicken breast fillets. LWT-Food Sci Technol 55: 263-288.

41. ICMSF (1986) Microorganisms in foods 2 Sampling for microbiological analysis: Principles and specific applications. ( $2^{\text {nd }}$ edtn), University of Toronto Press, Toronto.

42. Sagoo S, Board R, Roller S (2002) Chitosan inhibits growth of spoilage microorganisms in chilled pork products. Food Microbiol 19:175-182.

43. Darmadji P, Izumimoto M (1994) Effect of chitosan in meat preservation. Meat Sci 38: 243-254

44. Cheong JH, Kim KH, Kim CR (2001) Quality evaluation of refrigerated Korean beef loins treated with trisodium phosphate. Korean J Food Sci Anim Resour 1: $1-7$. 
Citation: Mukhtar S, Zahoor T, Randhawa MA, Iqbal R, Shabbir A, et al. (2018) Synergistic Effect of Chitosan and Clove Oil on Raw Poultry Meat. J Food Process Technol 9: 737. doi: 10.4172/2157-7110.1000737

Page 5 of 5

45. Chouliara E, Karatapanis A, Savvaidis I, Kontominas MG (2007) Combined effect of oregano oil and modified atmosphere packaging on shelf-life extension of fresh chicken breast meat, stored at $4^{\circ} \mathrm{C}$. Food Microbiol 24: 607-617.

46. Kannat SR, Rao MS, Chawala SP, Sharma A (2013) Effect of chitosan coating on shelf-life of ready- to-cook meat products during chilled storage. Food Sci Technol 53: 321-326.
47. Huang J, Chen Q, Qu M, Li S (2012) Chitosan based edible coatings for quality preservation of postharvest white leg shrimp (Litopenaeusvannamei). J Food Sci 77: 491-496.

48. Petrou S, Tsiraki M, Giatrakou V, Savvaidis IN (2012) Chitosan dipping or oregano oil treatment, singly or combined on modified atmosphere packaged chicken breast meat. Int J Food Microbiol 156: 264-271. 